\title{
Mosaic landscapes of SE Poland: should we preserve them?
}

\author{
Bogusława Baran-Zgłobicka • Wojciech Zgłobicki
}

Received: 15 January 2011/Accepted: 17 September 2011/Published online: 30 September 2011

(C) The Author(s) 2011. This article is published with open access at Springerlink.com

\begin{abstract}
Agricultural areas of SE Poland are characterised by small, family-owned agricultural holdings. Poland's accession to the EU has resulted in an increased availability of funds needed to change traditional agriculture practices. A question thus arises: should we preserve the economically unfavourable land use mosaic occurring here (more than 30 patches per square kilometre)? The study analyses the structure of the land cover using three test areas covering $100 \mathrm{~km}^{2}$. The main objective is to propose solutions that should be part of the model procedure within the system of agricultural use of loess areas in the future. The authors also attempts to determine whether traditional agroforestry can be a method for the agricultural use of these areas. Based on an analysis of maps for landforms, geology and land cover and landscape structure, the authors also propose guidelines to be considered in spatial agricultural management. The main output of the paper is a set of several maps together with quantitative descriptions and statistical analysis. The improvement of the area's landscape structure and the reduction of erosion risk, necessitate afforestation encompassing between 4.9 and $6.5 \%$ of the test areas. The implementation of land consolidation programmes should preserve the
\end{abstract}

B. Baran-Zgłobicka · W. Zgłobicki ( $₫)$ Institute of Earth Sciences, Maria Curie-Skłodowska University, Kraśnicka 2CD, 20-718 Lublin, Poland e-mail: wojciech.zglobicki@umcs.pl existing land use mosaic (traditional agroforestry) in areas threatened by erosion (9.0-15.4\% of the area).

Keywords Land cover structure $\cdot$ Mosaic landscapes · Traditional agroforestry $\cdot$ SE Poland

\section{Introduction}

Agricultural landscapes feature a mosaic of patches determined by natural and anthropogenic factors, and varying in terms of land cover type, size and shape. At present, human activity is the main factor influencing the spatial and temporal diversity of land cover (Dotterweich 2008; Geri et al. 2010; Kobayashi and Koike 2010). Agroforestry is one way of using the environment for agricultural purposes, and is regarded as an example of sustainable agriculture and an alternative to industrial-scale agricultural production (Lefroy et al. 1999; Jose 2009). In a broad sense, agroforestry relies on the deliberate introduction of trees, shrubs and pastures into the agricultural land use. The mosaic of land use, an essential feature of agroforestry, could be advantageous from the ecological, aesthetic, and sometimes economic perspective (Herzog 1998; Hildreth 2008; Jose 2009; Di Falco et al. 2010). Agroforestry helps to preserve a high degree of biodiversity, providing habitats for small mammals and several species (Bird 1998; Herzog 1998; Lefroy et al. 1999). Other advantages of this 
system include carbon sequestration, soil enrichment, and a positive impact on air and water quality (Jose 2009).

The agricultural areas of SE Poland are characterised by an extensive land use mosaic. The lack of ownership changes during the twentieth century has led to the preservation of family-based, an extensive agriculture characterised by very high land fragmentation with a mosaic of crops. The farming system in SE Poland is extensive, and most of the agricultural products are locally used and do not enter into the national or international market. According to Herzog (1998), traditional, fragmented orchards covered in Poland nearly 200,000 ha in 1996. In SE Poland, the most widespread plots are small used as arable lands, orchards, plantations or pastures, divided by hedgerows (field boundaries) with grass, shrubs and trees. In some places small woodland patches occur where farmers obtain timber. Such land cover structure resulted from the historical development of agriculture and it can be termed as a traditional agroforestry system (Herzog 1998). Three basic types of agroforestry systems can be distinguished (Hsiung et al. 1995): (a) agroforestry with crops dominant (trees along field boundaries), (b) agroforestry with forests (orchards and plantations in the land use structure), and (c) agroforestry with pasture-husbandry dominant leading to a mosaic of forests and pastures.

A good understanding of the historical reasons and character of land use changes enables a more accurate prediction of landscape development trends as well as more efficient landscape management (Dotterweich 2008). In the loess areas of SE Poland, forests constitute the most important land cover type, due to biodiversity conservation and protection against soil erosion. An analysis of present-day land use structure against the natural conditions provides the data required to assess the economic aspects of land use patterns, and enables the identification of a need for possible changes in the spatial planning process (Kim and Pauleit 2007; Beunen and Hagens 2009). Since Poland's accession to the European Union in 2004, local agriculture has received considerable financial assistance enabling significant changes in land use structure, including land consolidation. Therefore, it is particularly important to establish rules of procedure for measures that improve the economic efficiency of agricultural holdings while preserving the natural environments.
For these reason, the following questions were stated in this study: (i) should the existing land use mosaic in the agricultural areas of SE Poland be preserved and why? (ii) How can it be achieved?, and (iii) Can traditional agroforestry help us in the achievement of this goal? Consequently, the objectives of this paper were: (a) to determine the present land cover structure, especially forest patches, as well as historical and recent changes, (b) to assess key environmental determinants (erosion risk and landscape structure) of agriculture to prepare proposals for spatial management, and (c) to determine the areas where landscape mosaic should be preserved.

\section{Methods}

Study area

Surveys were conducted within three drainage basins (total area of about $100 \mathrm{~km}^{2}$ ), located in different meso-regions in SE Poland: (i) Wạwolnica $\left(28.2 \mathrm{~km}^{2}\right)$ in the Nałęczów Plateau, (ii) Wilczyce $\left(37.7 \mathrm{~km}^{2}\right)$ in the Sandomierz Upland, and Markowa $\left(35.2 \mathrm{~km}^{2}\right)$ in the Rzeszów Foothills (Fig. 1). The test areas selected for the study constituted typical, representative examples of agricultural areas of SE Poland, and are located in regions covered by fertile soils originating from loess. Markowa is characterised with the least varied land relief and cover, and where arable lands predominate. The specific feature of Wawolnica is the occurrence of diversified land relief, numerous gullies, and large patches of forests and plantations (berries). In Wilczyce, large areas are occupied by flat land (plateau tops and valley bottom) used for orchards and arable lands.

The three regions have features that are in common with agricultural land use due to the occurrence of fertile soils, as well as diverse land relief and high activity of soil erosion processes. The primary characteristics of the environments include: (i) predominance of loess surface deposits (59-78\% of the area), (ii) large share of areas with an inclination exceeding $6^{\circ}(22-25 \%)$, (iii) a clear predominance of brown soils, e.g. Luvisols and Cambisols (70-90\% of the area), and (iv) a large share of arable land in the land use structure (Baran-Zgłobicka 2004). The dense network of dry valleys and gullies lends a special appearance to the landscape. 


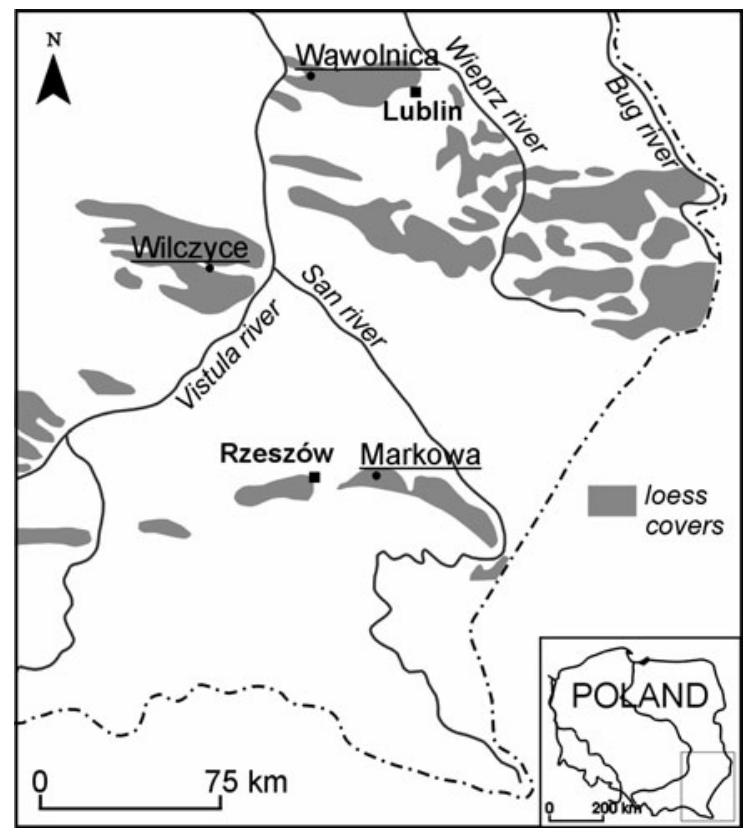

Fig. 1 Location of the studied areas

In SE Poland, small agricultural holdings prevail, e.g. in the Lublin region in 2008, there were 283,000 individual holdings with an average area of 7.7 ha (compared to the national average of $8.9 \mathrm{ha}$ ). A significant role in the region's agriculture is played by permanent crops comprising of fruit trees and plantations of berries. In 2007, such crops were grown in 67,500 agricultural holdings. Orchards in the Lublin region are dominated by apple trees $(22,000 \mathrm{ha})$, while plantations are dominated by currants (17,000 ha) and raspberries $(14,000$ ha) (Agriculture in Lublin Province in 2009, 2010).

The natural (potential) forests in the test areas are the sub-continental lime-oak-hornbeam forests (Tilio Carpinetum) of the Małopolska variety with beech (Fagus sylvatica) and upland fir (Abies alba). Habitats of this community occur on vast loess plateau tops. On the other hand, smaller areas in the neighbourhood of gullies and valley forms are a potential habitat for the stenothermic oak forest of the upland type (Potentillo albae-quercetum). A lowland elm-oak forest (FicarioUlmetum chrysosplenietosum) can occur in valley bottoms, beyond the floodplain zone, while a lowland riparian ash-elm forest (Ficario-Ulmetum typicum) can occur in the occasionally flooded zone. Today, the composition of tree species has largely been determined by humans, and shows a clear predominance of hornbeam (Carpinus betulus), oak (Quercus robur), beech (F. sylvatica) and larch (Larix decidua).

Metrics used to characterise the landscape

Spatial and statistical studies based on the map analysis were applied as the basic method. The main output is a set of several maps together with quantitative descriptions and some statistical analysis. Spatial and temporal diversity of land cover in the three test areas was analysed. Historical and contemporary maps, as well as aerial photographs, have been used for cartographic analysis: (a) Topograficzna Karta Królestwa Polskiego (Topographical Map of Polish Kingdom) scale 1:126,000 (1840), (b) Karte des westlichen Rußlands (Map of Western Russia) scale 1:100,000 (c. 1890), (c) Mapa Taktyczna Polski (Tactical Map of Poland) scale 1:100,000 (1935), (d) Mapy topograficzne (topographical maps) scale 1:10,000 and 1:100,000 (1970 and 1980), (e) Zdjęcia lotnicze (colour aerial photographs) scale 1:26,000 (1997), (f) Zdjęcia lotnicze (colour aerial photographs) scale 1:13,000 (2008), and (g) Szczegótowa Mapa Geologiczna Polski (Detailed Geological Map of Poland) 1:50,000.

Historical topographical maps (1840-1970) provided information on changes in the area of forests. An analysis of present-day land use was done using a map prepared based on aerial photographs and terrain mapping. A geomorphological map was prepared based on a modern 1:10,000 topographical map. Based on the described material, the following digital maps were prepared: (a) maps showing forest cover in 1840, 1890, 1930, 1970 and 1997, (b) maps showing land cover in 1997 and 2008, (c) geomorphological maps, and (d) geological maps showing surface deposits.

Using the described maps, we obtained the spatial metrics of land use patches, the changes occurred during 1997-2008, and the spatial metrics of forest patches (in 1840, 1890, 1930, 1970 and 1997). Determining the spatial metrics of land cover patches enables a qualitative assessment of the spatial structure of landscape, e.g. the number, size and shape of land use patches, and, consequently, a better understanding of the processes taking place in landscape along with their determinants (Ritters et al. 1995; Haines-Young and Chopping 1996; Corry and Lafortezza 2006; Ruiz and Domon 2009; Uuemaa et al. 2009; Geri et al. 2010). Spatial metrics available on the ArcView software and Patch Analyst extension 
were used (Elkie et al. 1999): (1) NumP: total number of patches in the landscape, (2) MPS: average patch size, (3) MEDPS: median patch size, (4) PSCoV: coefficient of variation of patches, (5) ED: edge density defined as a ratio of perimeter of patches and landscape area, (6) MPE: mean patch edge, (7) MSI: mean shape index, where 1 means a circular patch and bigger values indicates more complicated shape of the patch, and (8) MPAR: mean perimeter area ratio (for details about formulas see Moser et al. 2002).

In order to assess the internal variation of the forest cover, the size of forest patches was examined within 4-5 $\mathrm{km}^{2}$ sub-regions into which the test areas were divided. The highest, the lowest, and the mean value as well as the standard deviation were calculated for each patch in the particular years. The relationship between the geomorphology and spatial distribution of forest patches was also studied. It was also examined on what bedrock or surface deposit, and within which forms of relief, forest patches are located. It was thus possible to assess the effect of natural conditions on the contemporary distribution of forest patches. The determinants of historical changes in the range of forests were also analysed (for the Wawolnica test area). It was the only area with various types of sediments and various landforms where changes in the range of forest patches occurred.

Two series of ANOVA tests were carried out: (i) analysis of changes in the forest cover of a test area in the particular years, and (ii) analysis of differences in the forest cover of three test areas in the particular years. A hypothesis was tested about the lack of variation between the particular years (i) and particular areas (ii).

Spatial distribution of erosion risk

A potential erosion risk map has been prepared based on two criteria: (i) type of surface deposits, and (ii) land relief (Wischmeier and Smith 1978; Poesen et al. 2006). Three risk levels are distinguished: low, medium and high (Table 1). The map presents a general, qualitative assessment of erosion risk, and identifies areas that, due to the existing natural conditions conducive to erosion, should not be used as extensive fields with a single crop. The prepared map do not shows the real, present-day erosion intensity - it is related mainly to the land cover (a factor with high changeability in time).
The landscape structure

The spatial structure of landscape (landscape configuration) was determined based on the principles of Forman and Godron's patch-corridor-matrix model (Forman and Godron 1981, 1986). Two components were analysed on the map: ecological corridors (valley bottoms) and patches of land cover. Based on a geomorphological map, four types of valleys were distinguished: (a) river valleys, (b) valleys with a stream, (c) dry valleys, and (d) gullies. They are characterised by a different type of matter and energy circulation in time and space. The area of forests in the bottoms of valleys of different types was then analysed.

Proposals for spatial management process

Based on the analysis of the erosion risk and landscape structure, an outline of changes in land cover has been prepared: (1) afforestation to be carried out in areas with the highest erosion risk (Table 1) located within $50 \mathrm{~m}$ of the existing forests, (2) afforestation to be carried out in areas located in the bottom valleys within $100 \mathrm{~m}$ of the existing forests, (c) afforestation to be carried out in areas located within $25 \mathrm{~m}$ of the river channel, and (d) land use mosaic to be preserved in areas with the highest erosion risk (Table 1), located further than $50 \mathrm{~m}$ from the existing forests.

\section{Results}

Historical changes in forest cover

Changes in forest cover varied between the study areas. Over the last 170 years, the area covered by forests decreased in Wawolnica and increased in Wilczyce while in Markowa no important changes occurred (Fig. 2). The forest cover increased since the first half of the twentieth century, when the lowest forest cover for all test areas was observed. The greatest changes occurred in Wạwolnica and Wilczyce, the most important changes being: (a) in Wawolnica the forest cover decreased by $2.8 \mathrm{~km}^{2}$ over the last 100 years, where the greatest changes (30-11\%) occurred during the 1890-1935 period, after which the forest area increased again; (b) in Wilczyce the forest cover increased more than 
Table 1 Geological (surface sediments) and geomorphological (main relief forms with inclinations) criteria for preparing of erosion risk map

0-2 low risk, 3-5 medium risk, 6-8 high risk

\begin{tabular}{lllllll}
\hline & $\begin{array}{l}\text { Bottoms } \\
\text { of valleys } \\
\left(0-3^{\circ}\right)\end{array}$ & $\begin{array}{l}\text { Top } \\
\text { plateaus } \\
\left(0-3^{\circ}\right)\end{array}$ & $\begin{array}{l}\text { Gentle } \\
\text { slopes } \\
\left(3-6^{\circ}\right)\end{array}$ & $\begin{array}{l}\text { Moderate } \\
\text { slopes } \\
\left(6-12^{\circ}\right)\end{array}$ & $\begin{array}{l}\text { Steep } \\
\text { slopes } \\
\left(>12^{\circ}\right)\end{array}$ & Gullies \\
\hline Bedrock & 0 & 2 & 2 & 4 & 6 & 6 \\
Glacial tills & 0 & 2 & 2 & 4 & 6 & 6 \\
Alluvia & 1 & 3 & 3 & 5 & 7 & 7 \\
$\begin{array}{l}\text { Fluvioglacial } \\
\quad 1\end{array}$ & 3 & 3 & 5 & 7 & 7 \\
$\begin{array}{c}\text { Codiments } \\
\text { Colluvia }\end{array}$ & 2 & 4 & 4 & 6 & 8 & 8 \\
$\begin{array}{c}\text { Aeolian } \\
\text { sediments }\end{array}$ & 2 & 4 & 4 & 6 & 8 & 8 \\
\hline
\end{tabular}

five-fold over the last 100 years, where at the end of the nineteenth and beginning of the twentieth century it was less than $0.5 \%$ (Fig. 2), and greatest changes occurred during 1970-1997 period; (c) loess plateaus as well as low and medium slopes were deforested in Wąwolnica, while in Wilczyce this process was not observed; and (d) the forest mainly appeared in gullies and steep and medium slopes, where $82 \%$ of newlyafforested areas were located less than $100 \mathrm{~m}$ from gully edges.

\section{Present-day land cover}

Regional differences occur in the land cover in the three areas (Table 2). The area of grasslands is linked to the size of valley bottom areas (the highest is in Wawolnica with 14\%). In the case of Wilczyce, the natural determinants (the wide bottom of the Opatówka valley) and type of agriculture also play a significant role-orchards and market gardening prevail (14\% of the area), while livestock breeding is

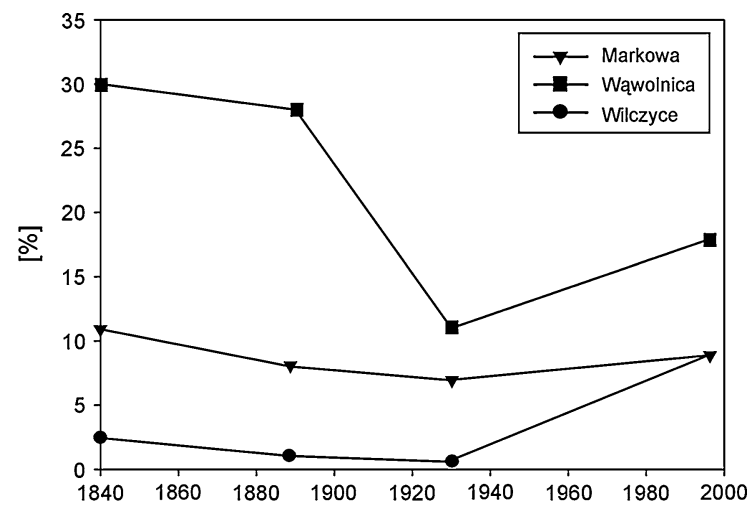

Fig. 2 Forest cover changes (1840-1997) in the test areas limited and vast areas in the bottom of the Opatówka valley have been turned into arable lands. Forests occupy small areas, but one exception is Wąwolnica, where forests grow in gully systems and within steep slopes (Table 2). Wastelands have a relatively small area, and usually occur in steep and medium slopes although in Wawwolnica they also occur on the plateau tops. In the Markowa test area arable lands with cereal and root vegetable crops predominate.

Present-day land use is characterised by the occurrence of a mosaic of grasslands, orchards, plantations and wastelands located within a matrix of arable lands. The patch density ranges from 20 to 30 per square kilometre (Table 3). The largest number of patches (per a unit of area) occurs within steep slopes (1.6 patch $\mathrm{ha}^{-1}$ ), while the lowest number occurs on plateau tops $\left(0.4\right.$ patch ha $\left.{ }^{-1}\right)$. The number of grassland and orchard patches in the particular test areas reaches or even exceeds 300 (Table 3 ). Their average size is $0.5-0.6$ ha and corresponds to the size of the individual fields. Only arable land patches are considerably larger, 1.2-2.2 ha. In Wąwolnica, numerous plantation and wasteland patches also occur. Combined with the considerable number of forest patches, the mosaic of land cover patches is quite complex (Fig. 3). On average, 10 grassland patches, 6 orchards, 5 plantations, 5 arable lands, 2 wastelands and 4 forest patches occur within a square kilometre in Wąwolnica.

Natural conditions of forest patches location

The contemporary distribution of forest patches in the test areas shows a clear connection with land relief (Table 4). They occur primarily within gullies and on steep slopes. The forest cover of areas with slopes of less than $6^{\circ}$ usually does not exceed $10 \%$, the only 
Table 2 Land cover in the test areas (in \% of total surface area)

\begin{tabular}{lccc}
\hline & Wąwolnica & Wilczyce & Markowa \\
\hline Arable lands & 54.0 & 63.0 & 66.0 \\
Orchards & 3.0 & 14.0 & 5.0 \\
Plantations & 5.0 & 0.5 & 0.5 \\
Grasslands & 14.0 & 7.0 & 12.0 \\
Forests & 18.0 & 9.0 & 9.0 \\
Wastelands & 2.0 & 2.0 & 0.5 \\
Built-up areas & 4.0 & 4.5 & 7.0 \\
\hline
\end{tabular}

exception being Wąwolnica. In Markowa and Wilczyce, the share of forest areas on plateau tops is lower than $1 \%$. Forest occur relatively rarely in valley bottoms except Wilczyce where the forest cover within valley bottoms reaches $13 \%$.

These results presented a strong spatial variation of forest distribution within the test areas (Fig. 4; Table 5). In Markowa, larger forest patches occur only in the southern part (the largest patch covers $1 \mathrm{~km}^{2}$ ), while the northern part is entirely devoid of forests. The most even distribution of forests is to be found in Wawolnica. The largest forest complexes linked with vast gully systems reach sizes of more than $1.5 \mathrm{~km}^{2}$. The smallest forest patches covered not more than $0.5 \mathrm{~km}^{2}$, occurring in Wilczyce, and were concentrated in the southern part of the test area and in the Opatówka valley bottom. There are only four forest patches of more than $0.1 \mathrm{~km}^{2}$, while the other test areas have twice that number of such patches.

An analysis of the size of forest patches within the sub-regions indicates a lack of homogeneity, both in the past and today, which is reflected in the range between extreme values and values of the standard deviation (Table 5). In most of the cases analysed, the standard deviation is higher than the mean. In Markowa and Wilczyce, vast areas devoid of trees occur, but there are also sub-regions where forests cover $30-40 \%$ of the area. The relatively smallest variation of the forest cover occurs in Wawolnica (Table 5). The ANOVA tests showed that no significant variation occurs in the forest cover in Markowa and Wawolnica in the particular years. In the case of Wilczyce, however, the variation is considerable ( $F=17.2$ where $\left.F_{\alpha}=4.68\right)$. Significant differences occur in the forest cover of the particular test areas in all periods under study, with the greatest differences being for 1890 , and the smallest for 2008. Compared to 1840 , the substratum of forest patches in Wawolnica in 1997 shows an increase in the case of the older bedrock (from 1 to $5 \%$ ) and colluvia (from 14 to $25 \%$ ), and a slight decrease for loess (from 69.3 to $68 \%$ ). The
Table 3 Spatial metrics for selected forms of land use in the test areas
NumP total number of patches in the landscape, $M P S$ average patch size, $M E D P S$ median patch size, PSCoV coefficient of variation of patches, $M S I$ mean shape index, MPAR mean perimeter area ratio

\begin{tabular}{lrrlrll}
\hline \multicolumn{1}{c}{ NumP } & MPS (ha) & MEDPS (ha) & PSCoV & MSI & MPAR (m/ha) \\
\hline Markowa & & & & & & \\
Arable lands & 70 & 20.8 & 2.2 & 257.8 & 1.9 & 434.9 \\
Grasslands & 253 & 1.6 & 1.0 & 142.6 & 1.6 & 601.5 \\
Orchards & 242 & 0.7 & 0.4 & 138.5 & 1.4 & 751.6 \\
Plantations & 12 & 0.6 & 0.6 & 54.0 & 1.4 & 687.9 \\
Wastelands & 13 & 0.4 & 0.4 & 52.5 & 1.4 & 796.2 \\
Wạwolnica & & & & & & \\
Arable lands & 151 & 9.6 & 1.7 & 218.5 & 1.9 & 485.9 \\
Grasslands & 272 & 1.5 & 0.7 & 251.6 & 1.6 & 655.3 \\
Orchards & 174 & 0.5 & 0.3 & 145.9 & 1.4 & 840.9 \\
Plantations & 155 & 0.9 & 0.6 & 112.4 & 1.6 & 714.0 \\
Wastelands & 68 & 0.9 & 0.5 & 129.2 & 1.5 & 733.7 \\
Wilczyce & & & & & & \\
Arable lands & 108 & 21.8 & 1.2 & 457.1 & 1.8 & 490.6 \\
Grasslands & 125 & 2.2 & 1.0 & 139.9 & 1.5 & 503.7 \\
Orchards & 312 & 1.7 & 0.8 & 140.6 & 1.5 & 596.3 \\
Plantations & 6 & 0.7 & 0.5 & 56.5 & 1.3 & 587.8 \\
Wastelands & 61 & 1.3 & 0.9 & 94.4 & 1.5 & 571.4 \\
\hline
\end{tabular}


Fig. 3 Land use at presentday (2008) in Wąwolnica test area: 1 arable lands, 2 orchards, 3 plantations (berries), 4 grasslands, 5 wastelands, 6 forests, 7 built-up areas, 8 rivers, and 9 roads

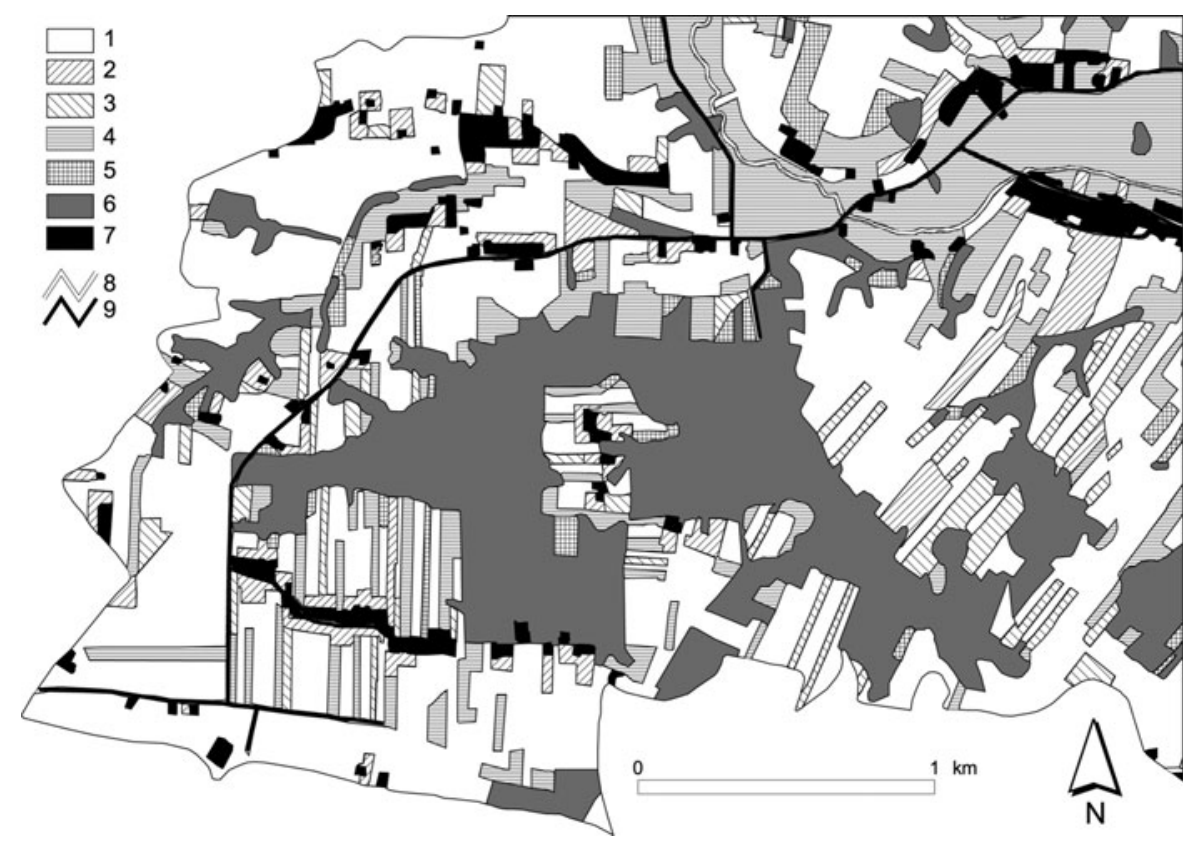

Table 4 Areas covered by forests in 2008 (in \%)

\begin{tabular}{lllllrr}
\hline Test area & $\begin{array}{l}\text { Plateau tops } \\
\left(0-3^{\circ}\right)\end{array}$ & $\begin{array}{l}\text { Gentle slopes } \\
\left(3-6^{\circ}\right)\end{array}$ & $\begin{array}{l}\text { Medium slopes } \\
\left(6-12^{\circ}\right)\end{array}$ & $\begin{array}{l}\text { Steep slopes } \\
\left(>12^{\circ}\right)\end{array}$ & $\begin{array}{l}\text { Gullies } \\
\text { of valleys }\end{array}$ \\
\hline Markowa & 1.0 & 4.7 & 18.5 & 35.7 & 76.0 & 5.0 \\
Wąwolnica & 9.0 & 13.0 & 20.0 & 30.0 & 86.0 & 4.0 \\
Wilczyce & 0.4 & 2.2 & 6.9 & 17.3 & 90.0 & 13.2 \\
\hline
\end{tabular}

forest cover shrank within all landforms except gullies during the period analysed. Deforestation occurred primarily on plateau tops (area covered by forest decreased from 21 to $8 \%$ ), gentle slopes (from 27 to $13 \%$ ) and valley bottoms (from 9 to $4 \%$ ). Steep slopes were least affected by the process (a fall from 39 to $30 \%)$.

Recent changes in land use

Considerable changes in land use, affecting $8 \%$ of the study area, occurred in Wawolnica during the 1997-2008 period. Plantations, wastelands and forests increased while grasslands decreased. The progressive decreased meadows and pastures resulted from the widespread fall in livestock numbers, particularly cattle, e.g. in the Lublin Province there were 262,000 livestock in 2002, and 184,000 in 2009 (Agriculture in Lublin Province in 2009, 2010). Basically, no changes were recorded for arable land and orchards.
The process of land abandonment, manifested in the increasing area of wastelands, also occurred in the other two test areas (Tables 6, 7). Thirty-two hectares of primarily arable lands and grasslands were excluded from agricultural use in Markowa and 110 ha in Wilczyce (3\% of the total area). The greatest changes occurred in the Opatówka River valley in Wilczyce, and on medium and steep slopes in Markowa and Wąwolnica.

Spatial metrics of forest patches

During the 1840-1997 period, the number of patches increased in Wawolnica while their average size (median) fell from 18.6 to 4.2 ha (Table 8). The patch size coefficient of variation and patch edge density increased (three times). The patch shape diversity was greater as the MSI and MPAR values increased. Similar patterns were observed in the Wilczyce area, where there were no more than five forest patches 

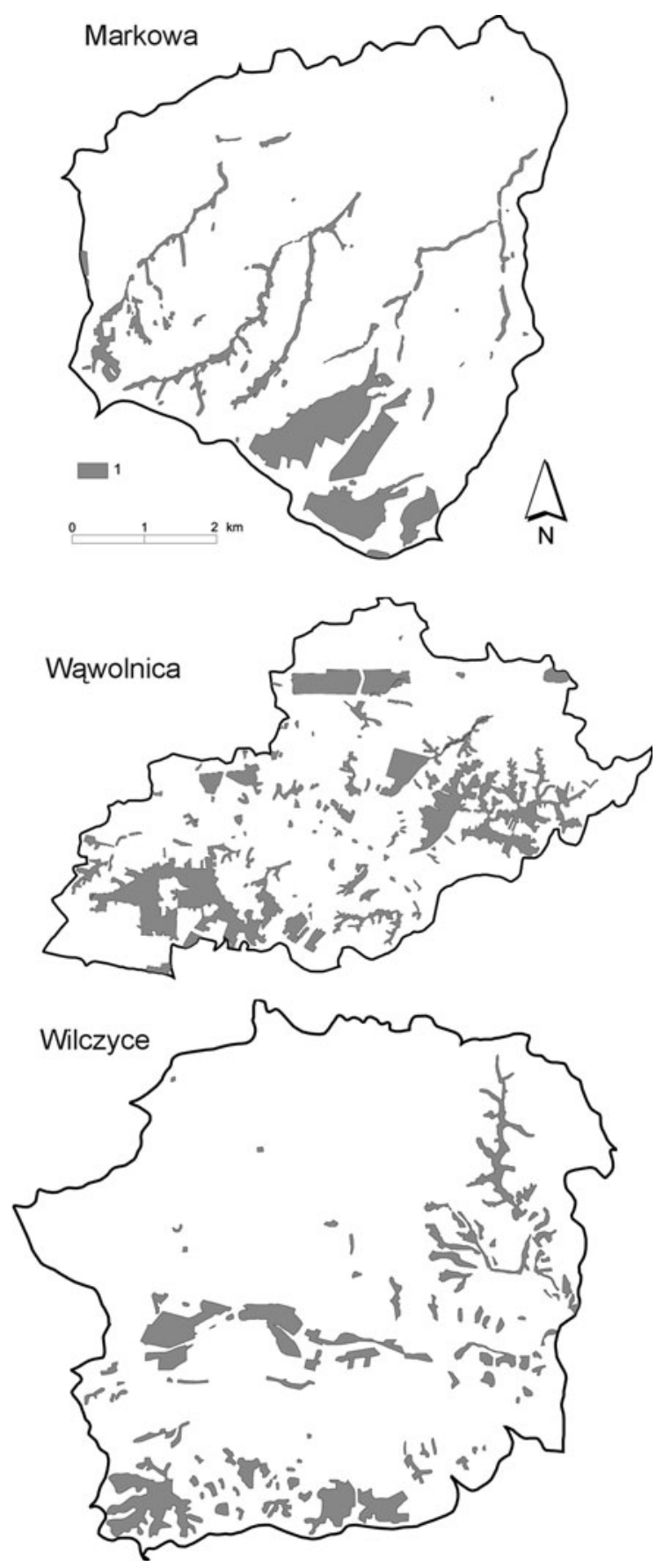

Fig. 4 Present-day (2008) forest patches in test areas: 1 forest patches

before 1997. Relatively, the smallest differences between patch parameters were observed in Markowa. The number of small patches in the test areas began to rise considerably after 1970 . Nowadays the number of forest patches in the particular test areas is similar (Table 9). The median patch sizes in Markowa and Wawolnica are similar while the median size in Wilczyce is higher. Small patches predominate in all three areas, the largest ones ranging from 35 ha in Markowa to 157 ha in Wawolnica. The edge density is the highest in Wawolnica and the lowest in Wilczyce. In Markowa and Wawolnica, the average patch edge is $1300 \mathrm{~m}$ long. Since long and narrow forest patches occur in Markowa, shape indices reaches the highest values in this area.

Erosion risk assessment and landscape structure

In Markowa, the areas of strong potential erosion represent $21 \%$ of the study area. They are located mainly in the south, in the Carpathian escarpment zone and within steep slopes of some valleys. High-risk areas in Wawolnica account for $27 \%$ of the total area and encompass gullies with the adjacent steep slopes, the sides of the Bystra valley and some trough-shaped valleys (Fig. 5). In Wilczyce, strong erosion occurs on $28 \%$ of the area, in gullies and on steep slopes, and it also occurs on medium slopes within colluvia and loess formations.

In Markowa, low-risk areas account for $12 \%$ of the test area, and comprise the bottom of the Markówka valley and the bottoms of other small valleys. Medium-risk areas occur on plateau tops in the northern and central part of the area (67\%). In Wawolnica, low-risk areas constitute $12 \%$ of the entire test area, and comprise the valley bottoms and flat parts of the northern and central part of the area. Medium risk occurs on $60 \%$ of the area, primarily on plateau tops. In Wilczyce, low-risk areas account for $19 \%$ of the test area, and comprise the bottom of the Opatówka valley and trough-shaped valleys. Medium risk occurs on $53 \%$ of the Wilczyce test area, on the plateau top, particularly in the central part of the lefthand side of the area.

Valley zones occupy the largest part of the area $(22 \%)$ in Wilczyce. This distribution results in a large area covered by the valley of the Opatówka River (12\%), dry valleys (5\%) and gullies (4\%). Gully areas (7\%) and the Bystra River valley (7.5\%) represent a significant area in Wąwolnica. Altogether valleys constitute $17 \%$ of the area. Valleys with a stream represent the largest area $(6 \%)$ of the valley zones in Markowa. The river valley has a higher forest cover 
Table 5 Basic statistical characteristics of forest areas in subregions (in \%)

\begin{tabular}{llllclc}
\hline $\begin{array}{l}\text { Test area, } \\
\text { year }\end{array}$ & $\begin{array}{l}\text { Number of } \\
\text { subregions }\end{array}$ & $\begin{array}{l}\text { Minimal } \\
\text { value }\end{array}$ & $\begin{array}{l}\text { Maximal } \\
\text { value }\end{array}$ & Mean & $\begin{array}{l}\text { Geometric } \\
\text { mean }\end{array}$ & $\begin{array}{l}\text { Standard } \\
\text { deviation }\end{array}$ \\
\hline $\begin{array}{l}\text { Markowa } \\
1890\end{array}$ & 8 & 0.0 & 33.9 & 10.7 & - & 14.6 \\
1930 & 8 & 0.0 & 39.8 & 9.2 & - & 13.9 \\
1970 & 8 & 0.0 & 42.0 & 6.3 & - & 16.1 \\
2008 & 8 & 0.7 & 43.5 & 10.5 & 5.2 & 15.3 \\
Wawolnica & & & & & & \\
1890 & 7 & 2.0 & 60.0 & 25.6 & 17.3 & 20.0 \\
1930 & 7 & 2.0 & 20.0 & 10.1 & 8.2 & 6.0 \\
1970 & 7 & 3.0 & 28.0 & 15.6 & 12.8 & 8.6 \\
2008 & 7 & 4.0 & 29.0 & 17.5 & 14.9 & 8.5 \\
Wilczyce & & & & & & 0.7 \\
1890 & 8 & 0.0 & 2.0 & 0.6 & - & 3.1 \\
1930 & 8 & 0.0 & 3.0 & 0.6 & - & 6.2 \\
1970 & 8 & 0.0 & 9.0 & 1.4 & - & 3.2 \\
2008 & 8 & 0.1 & 15.2 & 8.4 & & \\
\hline
\end{tabular}

Table 6 The area of cultivated fields (in ha) converted into wastelands in the years 1997-2008

\begin{tabular}{llll}
\hline Test area & \multicolumn{3}{l}{ Land use in 1997} \\
\cline { 2 - 4 } & $\begin{array}{l}\text { Arable } \\
\text { lands }\end{array}$ & $\begin{array}{l}\text { Orchards and } \\
\text { plantations }\end{array}$ & Grasslands \\
\hline Markowa & 6.0 & 0.0 & 26.0 \\
Wąwolnica & 15.0 & 0.0 & 27.0 \\
Wilczyce & 39.0 & 0.3 & 68.0 \\
\hline
\end{tabular}

than the entire study area only in Wilczyce, while Markowa and Wawolnica it is very low (2-3\%). A very low forest cover occurs in the bottoms of dry valleys, while in valleys with small streams it is clearly higher (9-25\%). Forests occupy nearly the entire area of gullies $(87-93 \%)$.

Numerous built-up areas occur in valley zones, particularly in Wilczyce where $37 \%$ of built-up areas are located in valleys. The percentage is $23 \%$ in Markowa, and $14 \%$ in Wawolnica. Such a "separation" of tributary valleys from the main valley disrupts the functioning of the entire ecological system of the area. In Wilczyce and Wawolnica, large areas in the bottoms of river valleys are occupied by arable fields (20 and 14\% respectively). Grasslands predominate here, covering between 54 and $77 \%$ of the area.

\section{Proposals for spatial management}

Based on the analysis of the erosion risk and landscape structure, an outline of changes in land cover (afforestation) has been prepared and the scope of the necessary measures determined. The scope of the changes encompasses between 4.9 and $6.5 \%$ of the test areas (Table 10). The differences result from the natural conditions prevailing in the test areas. For example in Wawolnica, low and medium slopes, still used for agriculture, extend over vast areas (Fig. 6). Another category is represented by areas with a diverse land use mosaic that should be excluded from land consolidation programmes. Such areas are the smallest in Markowa and the largest in Wilczyce, which results from the intensive use of the land for
Table 7 Location of new wastelands formed in the period 1997-2008 against the relief (in \%)

\begin{tabular}{lllllll}
\hline Test area & $\begin{array}{l}\text { Top } \\
\text { plateaus }\end{array}$ & $\begin{array}{l}\text { Gentle } \\
\text { slopes }\end{array}$ & $\begin{array}{l}\text { Moderate } \\
\text { slopes }\end{array}$ & $\begin{array}{l}\text { Steep } \\
\text { slopes }\end{array}$ & $\begin{array}{l}\text { Bottoms } \\
\text { of valleys }\end{array}$ & Total \\
\hline Markowa & 0.02 & 0.10 & 0.47 & 0.24 & 0.02 & 0.85 \\
Wạwolnica & 0.28 & 0.28 & 0.53 & 0.39 & 0.10 & 1.58 \\
Wilczyce & 0.05 & 0.20 & 0.79 & 0.45 & 2.53 & 4.02 \\
\hline
\end{tabular}


Table 8 Changes in forest patches spatial metrics in the years 1840-1997

\begin{tabular}{|c|c|c|c|c|c|c|c|c|}
\hline & NumP & MPS (ha) & MEDPS (ha) & PSCoV & $\mathrm{ED}(\mathrm{m} / \mathrm{ha})$ & MPE (m) & MSI & $\operatorname{MPAR}(\mathrm{m} / \mathrm{ha})$ \\
\hline \multicolumn{9}{|c|}{ Markowa } \\
\hline 1890 & 9 & 24.6 & 7.3 & 109.6 & 88.3 & 2174.9 & 1.4 & 172.1 \\
\hline 1930 & 8 & 26.1 & 16.3 & 64.6 & 100.7 & 2629.4 & 1.6 & 152.6 \\
\hline 1970 & 4 & 56.2 & 34.1 & 56.6 & 84.0 & 4718.4 & 1.8 & 90.4 \\
\hline $1997^{\mathrm{a}}$ & 22 & 15.7 & 4.1 & 147.6 & 213.5 & 3353.7 & 2.8 & 420.2 \\
\hline \multicolumn{9}{|c|}{ Wąwolnica } \\
\hline 1890 & 12 & 64.2 & 18.6 & 110.4 & 76.4 & 4911.0 & 1.9 & 150.6 \\
\hline 1930 & 33 & 9.6 & 2.7 & 202.6 & 149.5 & 1441.8 & 1.4 & 284.9 \\
\hline 1970 & 21 & 27.3 & 7.5 & 162.7 & 201.3 & 4374.7 & 2.5 & 277.3 \\
\hline $1997^{\mathrm{a}}$ & 37 & 13.2 & 4.2 & 215.5 & 219.1 & 2888.1 & 2.2 & 385.5 \\
\hline \multicolumn{9}{|c|}{ Wilczyce } \\
\hline $1840^{\mathrm{b}}$ & 1 & 97.1 & 97.1 & 0.0 & 50.2 & 4879.8 & 1.4 & 50.3 \\
\hline 1890 & 4 & 6.8 & 5.0 & 56.6 & 241.2 & 1655.6 & 1.6 & 233.4 \\
\hline 1930 & 2 & 8.6 & 3.4 & 59.7 & 189.4 & 1628.1 & 1.5 & 208.8 \\
\hline 1970 & 5 & 21.4 & 18.2 & 82.9 & 173.1 & 3703.5 & 2.2 & 213.9 \\
\hline $1997^{\mathrm{a}}$ & 87 & 3.8 & 0.9 & 237.7 & 289.5 & 1094.0 & 1.7 & 628.1 \\
\hline
\end{tabular}

NumP total number of patches in the landscape, MPS average patch size, MEDPS median patch size, $P S C o V$ coefficient of variation of patches, $E D$ edge density, MPE mean patch edge, MSI mean shape index, MPAR mean perimeter area ratio

${ }^{\text {a }}$ Only patches bigger then $10,000 \mathrm{~m}^{2}$ were analyzed (accuracy of historical data)

b For the Markowa and Wąwolnica test areas only total area covered by forests in 1840 were calculated

Table 9 Present-day spatial metrics of forest patches (data for all patches)

\begin{tabular}{lcllllllr}
\hline Test area & NumP & MPS (ha) & MEDPS (ha) & PSCoV & ED (m/ha) & MPE (m) & MSI & MPAR (m/ha) \\
\hline Markowa & 107 & 3.1 & 0.6 & 313.0 & 39.9 & 1310.7 & 2.6 & 1073.7 \\
Wąwolnica & 94 & 5.4 & 0.5 & 349.4 & 43.8 & 1312.2 & 1.7 & 704.1 \\
Wilczyce & 118 & 2.7 & 1.1 & 236.7 & 28.7 & 916.2 & 1.7 & 595.3 \\
\hline
\end{tabular}

NumP total number of patches in the landscape, MPS average patch size, MEDPS median patch size, PSCoV coefficient of variation of patches, $E D$ edge density, $M P E$ mean patch edge, $M S I$ mean shape index, MPAR mean perimeter area ratio

orchards. The Riparian buffer strips cover the largest area in Markowa due to the high density of streams. All the four categories above represent between 14 and $21 \%$ of all the test areas (Table 10). This range could be regarded as the necessary minimum area that should be used according to the recommendations set out in this study.

\section{Discussion}

The structure of present-day spatial patterns in SE Poland has been influenced by the same historical determinants and socio-economic processes. While the first major landscape transformations were initiated in the Neolithic period, a genuine settlement and economic revolution occurred in the fourteenth century. Town charters introduced a peculiar forest strip pattern to the landscape. Over time, the original strips were divided, which resulted in the characteristic vista of narrow strips. This centuries-old land use pattern can be easily discerned today in the landscape. Important changes in landscape were also linked to the development of manorial economy (sixteenth century), and involved changes in land use pattern. The size of peasants' farm holdings decreased to as 
Fig. 5 Potential erosion risk and forests in Wąwolnica test area: 1 forests, 2 gullies, and 3 erosion risk (based on Table 1)

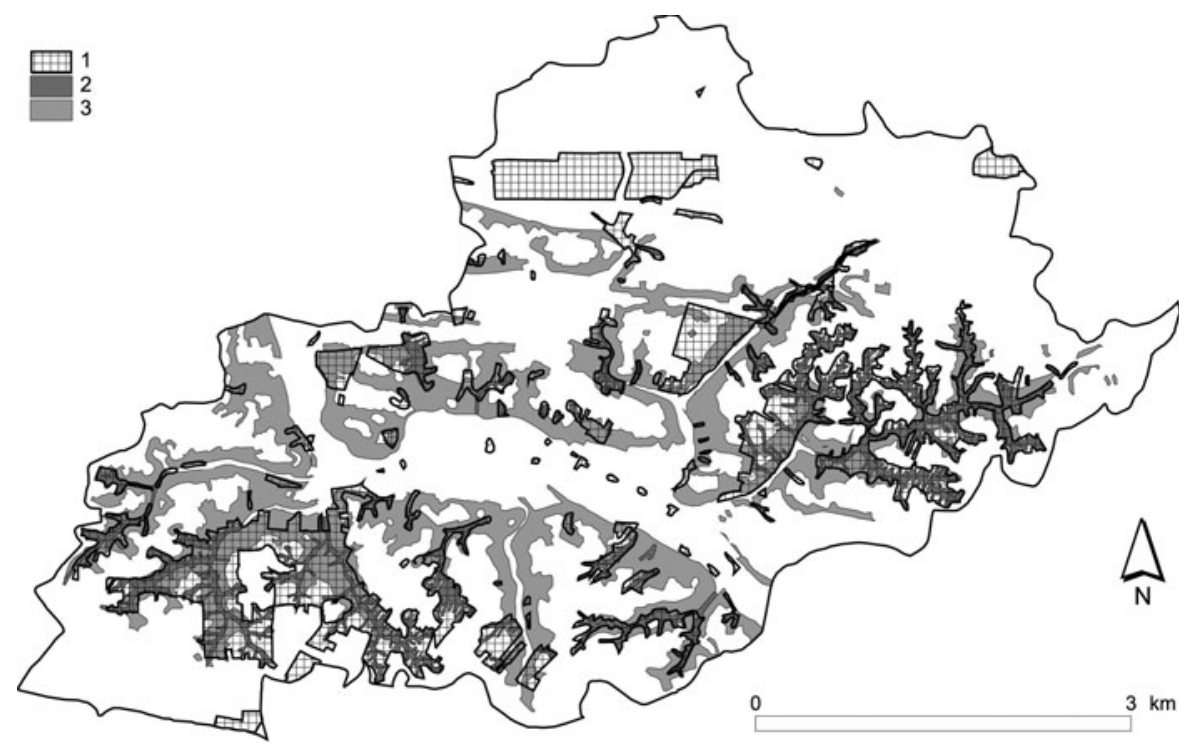

Table 10 Scope of land use changes and preservation of land cover mosaic

\begin{tabular}{llll}
\hline & Markowa (ha) & Wilczyce (ha) & Wạwolnica (ha) \\
\hline Afforestation (erosion threat) $^{\text {a }}$ & 59 & 95 & 89 \\
Afforestation (bottoms of valleys) $^{\text {b }}$ & 43 & 73 & 62 \\
Afforestation (riparian buffer strips) $^{\text {c }}$ & 86 & 30 & 33 \\
Preservation of land use mosaic $^{\text {d }}$ & 302 & 588 & 250 \\
Total $(\%)$ & 14.0 & 20.7 & 15.5 \\
\hline
\end{tabular}

${ }^{a}$ Afforestation to be carried out in areas with the highest erosion risk (Table 1), located within $50 \mathrm{~m}$ of the existing forests

b Afforestation to be carried out in areas located in valley bottoms within $100 \mathrm{~m}$ of the existing forests

c Afforestation to be carried out in areas located within $25 \mathrm{~m}$ of the river channel

${ }^{\mathrm{d}}$ Land use mosaic to be preserved in areas with the highest erosion risk (Table 1), located further than $50 \mathrm{~m}$ from the existing forests

little as 1.5 ha. In the mid-nineteenth century, inheritance division and splitting up of land became major factors shaping the rural settlement network, and the last stage of major deforestations occurred at that time. It should be stressed that in the twentieth century, mass-scale consolidations were not carried out in the SE Poland, and traditional family-based agriculture was not replaced by large-scale farm production. The above-mentioned processes have led to the formation of a unique and valuable landscape - a regional variety of the Pan-European landscapes, "Poland's strip fields" (Meeus 1995). A question thus arises as to how the changes in the agricultural land use in the loess areas of SE Poland should be carried out in the future. In our opinion, the process of changing the agricultural land use structure should encompass the partial preservation of the existing land cover mosaic.

\section{Landscape mosaic}

The metrics used enable an accurate assessment of the land use structure and forest patch structure (as the most important factor from the perspective of biodiversity). These metrics can be grouped into several types: total and per-class number of patches, sizebased metrics, shape-based metrics, and edge-based metrics. The number of patches defines the general structure of landscape, and it can also indicate the number of sub-populations connected with a specific type of habitat. The shape of patches influences the 
Fig. 6 Proposals of land cover management in Wąwolnica test area: 1 present-day forests, 2 afforestation to avoid erosion risk, 3 afforestation in bottom of valleys, 4 preservation of land use mosaic, 5 river (Bystra), and 6 riparian buffer strips

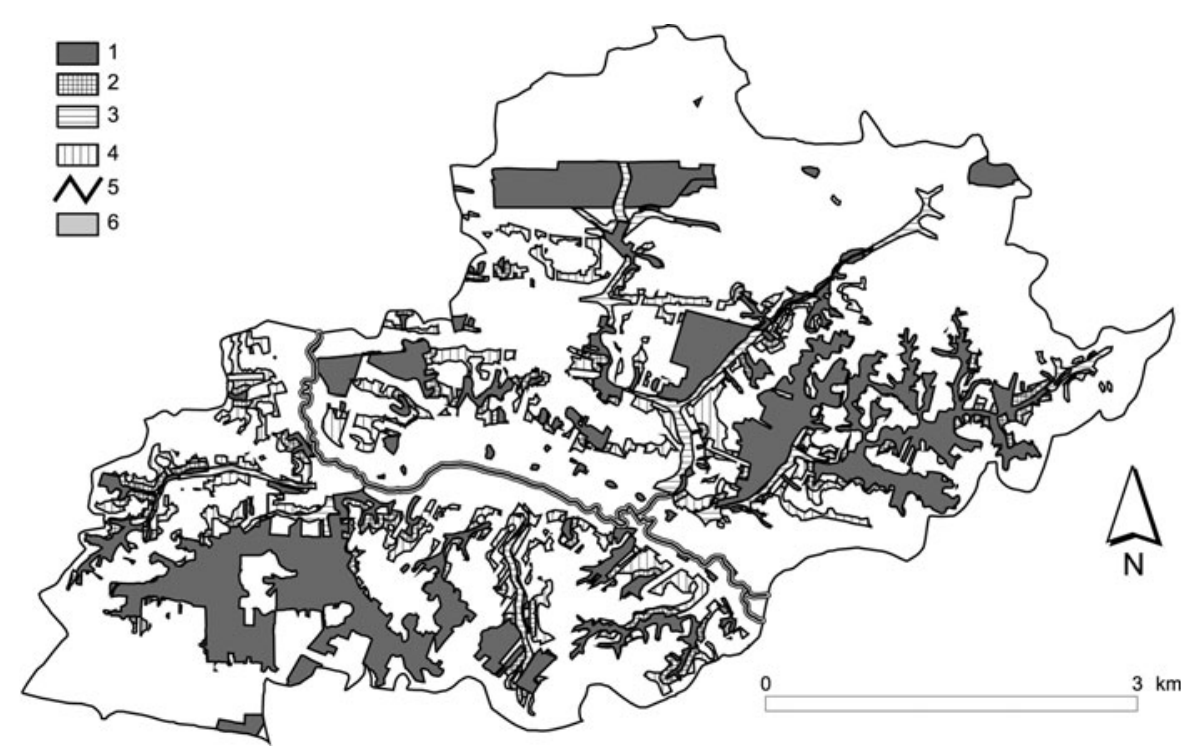

migration of species and succession of forest communities. Edge-based metrics are used to assess the processes of habitat disappearance and patch fragmentation (Buechner 1989; McGarigal and Marks 1995; Moser et al. 2002; Uuemaa et al. 2009; Geri et al. 2010).

A very strong fragmentation of present-day land use was found within the test areas. The forest patches occurring here are small and of varied shapes, which is not advantageous from the perspective of preserving habitats and biodiversity. The test areas are characterised by large internal differences in the occurrence of forests that are concentrated mainly in gullies and slopes with higher gradients. Changes in land cover occurring today are based on terminating the cultivation of areas with the worst natural conditions (steep slopes and dense gully network).

The high diversity of land cover constitutes an important factor that enriches the structure of the landscape and enhances landscape aesthetic values (With et al. 1997; Herzog 1998; Lefroy et al. 1999; Waldhardt et al. 2004). Numerous hedgerows play an important ecological role as corridors and key habitats (Forman and Baudry 1984; Davies and Pullin 2007; Lotfi et al. 2010). The existing mosaic of arable lands, grasslands, orchards, fruit tree plantations and numerous hedgerows (trees and shrubs) along agricultural terraces, occurring in the loess areas of SE Poland, constitute in our opinion an example of traditional agroforestry systems.
Erosion risk and landscape structure

The occurrence of a high level of risk on nearly onethird of the test areas shows that soil erosion is a serious problem. In our opinion, the major goals of the changes in land use should be to prevent erosion processes, improve the structure of landscape, and preserve the land mosaic in part of the area. The first two goals should be achieved by the afforestation of steeper slopes. Furthermore, the amount of soil material discharged to river systems can be effectively reduced through the afforestation of valley bottoms (Rodzik et al. 2009). Valley bottoms also retain pollutants and nutrients transported from fields (Zgłobicki and Rodzik 2007). Increased forest cover in these areas and the introduction of riparian buffer strips would markedly reduce the possibility of contamination and eutrophication of rivers. Given the occurrence of fertile soils in the areas studied, the afforestation programme may not be carried out on vast tracts of land. The programme should be complemented by cultivation systems mitigating the erosion risk and advantageous from the biodiversity perspective. This function can be fulfilled by traditional agroforestry systems with a mosaic of grasslands, orchards and hedgerows (trees and shrubs) (Bird 1998; Herzog 1998; Lefroy et al. 1999; Jose 2009).

A diverse land use mosaic is one of the most efficient methods of preventing soil erosion (Boardman and Poesen 2006; Poesen et al. 2006). In our 
opinion, land consolidation should be implemented primarily on plateau tops and gentle slopes where the establishment of large fields will not increase the risk of erosion. Steeper slopes should not be included, and hedgerows along field boundaries should not be removed in the process. Factors such as small-sized fields, the lack of monocultures and occurrence of numerous hedgerows clearly reduce the intensity of water-induced erosion of soils (Boardman and Poesen 2006). Estimates calculated for the Wawolnica commune indicate that changes in land cover (increased forest cover and increased area of meadows and pastures) in the 1962-1997 period caused an approx. $20 \%$ reduction of material eroded from slopes (BaranZgłobicka and Zgłobicki 2002).

Valley corridors play an essential role in the functioning of loess-covered areas because they are a place of concentration of water flows and the related erosion-sedimentation cycle. Finally, valley bottoms function as geochemical barriers within which pollutants may accumulate (Zgłobicki and Rodzik 2007). The functioning and accessibility of those corridors are also influenced by the structure of land use in the central areas of matrices (the headwater zones of the erosion-sedimentation cycle). Besides enabling passage and serving as links, the valley corridors, mainly in the form of zones (strip corridors), also function as habitats (Rosenberg et al. 1997; Beunen and Hagens 2009). The overlapping area between corridors and forest patches is crucial to the functioning of a given area. The proposed map showed areas where supplementary afforestation should be carried out in order to improve the landscape structure (facilitated migration, reduced habitat fragmentation, greater biodiversity).

\section{Spatial management}

Based on the conducted analyses, directions for the spatial development of the loess areas of SE Poland have been proposed. The prevailing environmental conditions determine the specific requirements and limitations on land use in some areas. They occupy relatively large tracts of land, from 14 to $21 \%$ (Table 10). The obtained figures can be treated as model (typical) figures for the loess areas of SE Poland.

The requirements include preserving the land use mosaic in some areas (e.g. excluding them from land consolidation programmes) and increasing the forest cover in areas threatened by erosion and are important from the perspective of biodiversity (Fang 2009; Staniak 2009). It seems appropriate to implement solutions that would support the environmentally advantageous changes taking place here: afforestation of steep slopes and gullies (1840-1997), increase in the area of wastelands and forests on medium and steep slopes. The above phenomena result from the fact that erosion could be a driver of land-use change (Bakker et al. 2005; Zgłobicki and Baran-Zgłobicka 2011).

The proposals presented in the study have the character of general guidelines because in conditions of fragmented private land ownership, the possibilities of their implementation in individual agricultural holdings are limited. The financial assistance of the state is required in order to maintain the traditional land use in some of these areas. Such measures are supported by the Agri-Environmental Scheme among other instruments within the Programme for the Development of Rural Areas 2007-2013. The following packages available within the scheme are particularly crucial for the preservation of the unique mosaic landscape of SE Poland: extensive permanent grasslands; protection of endangered bird species and habitats outside Natura 2000 areas; protection of endangered bird species and habitats within Natura 2000 areas; preservation of endangered genetic resources in agriculture; soil and water conservation. The Programme also comprises a scheme for the "Improvement and development of infrastructure related to the development and harmonisation of agriculture and forestry. Scheme I: Land consolidation". It would also be necessary to amend Polish law concerning afforestation because introduction of forests on high-quality soils is currently not allowed.

Adverse developments include the decreasing area of grasslands and disappearance of old domestic orchards that were also used as silvopasture in the past. These processes are primarily linked to the decreasing number of cows that used to be grazed in such areas. The speed of these changes could be slowed down by implementing agri-environmental schemes.

From an economic point of view, extensive land fragmentation is generally regarded as a negative factor. It results in decreased productivity of agricultural holdings and lack of spending on the modernisation of production (Dirimanova 2006). Land consolidation projects are often treated as a 
means of increasing the productivity of agriculture in Central Europe (Pašakarnis and Maliene 2010). However, land consolidation programmes cannot be carried out in direct imitation of Western European experiences (Van Dijk 2007). Improperly conducted changes may cause some adverse changes from the ecological (lower biodiversity) and economic perspective. It should be emphasised that until now the land consolidation process in SE Poland has encompassed small tracts of land: less than $0.5 \%$ of the loess areas in the Lublin Province, according to the author's calculations.

There is no doubt that farms with fragmented land are less profitable (Di Falco and Perrings 2005). However, land fragmentation makes it possible to better adapt crop cultivation to environmental conditions, and reduce the risk of losses in the case of adverse weather events. It also ensures greater flexibility, whereby production can be adapted to the existing demand in the market (Di Falco et al. 2010). Studies also indicate that "the effects of agroforestry on agricultural output are positive, though not always significant" (Hildreth 2008).

\section{Conclusions}

The landscape characteristics' of the loess areas of SE Poland are unique on a European scale. Their primary feature is the land use mosaic resulting from the extensive fragmentation of land ownership. Two contradictory processes can be observed here today: (i) a widespread decrease in the intensity of agriculture (increased area of wastelands and forests), and (ii) a limited process of land consolidation and expansion of the area of agricultural holdings. The latter process should be adapted to environmental conditions (particularly to land relief). Model solutions for changing the land cover structure should be developed. The consolidation measures should be carried out in areas with gentle slopes, and should be accompanied by an increase in the forest cover on steep slopes and in valley bottoms as well as the preservation of the land use mosaic (traditional agroforestry) in some areas. It is indispensable to conduct further studies concerning the economic aspects of the suggested ways of land use.

Acknowledgments The authors wish to thank the anonymous reviewers for their comments to this paper. The project has been financed by Narodowe Centrum Nauki-the National Science Centre (project no N N305 262840).

Open Access This article is distributed under the terms of the Creative Commons Attribution Noncommercial License which permits any noncommercial use, distribution, and reproduction in any medium, provided the original author(s) and source are credited.

\section{References}

Agriculture in Lublin Province in 2009 (2010). (Rolnictwo w województwie lubelskim w 2009), Urząd Statystyczny w Lublinie, Lublin

Bakker MM, Govers G, Kosmas C, Vanacker V, van Oost K, Rounsevell M (2005) Soil erosion as a driver of land-use change. Agric Ecosyst Environ 105:467-481

Baran-Zgłobicka B (2004) Badania krajobrazowe wybranych obszarów lessowych jako podstawa oceny możliwości wykorzystania terenu $\mathrm{w}$ procesie planowania przestrzennego. UMCS, PhD thesis (in Polish)

Baran-Zgłobicka B, Zgłobicki W (2002) Współczesne zmiany natężenia erozji gleb na wyżynach lessowych (na przykładzie gminy Wąwolnica, Polska SE). Zesz Probl Post Nauk Roln 487:25-33

Beunen R, Hagens JE (2009) The use of the concept of ecological networks in nature conservation policies and planning practices. Landsc Res 34:563-580

Bird PR (1998) Tree windbreaks and shelter benefits to pasture in temperate grazing systems. Agrofor Syst 41:35-54

Boardman J, Poesen J (2006) Soil erosion in Europe: major processes, causes and consequences. In: Boardman J, Poesen J (eds) Soil erosion in Europe. Wiley, Chichester, pp 479-487

Buechner M (1989) Are small-scale landscape features important factors for field studies of small mammal dispersal sinks? Landsc Ecol 2:191-199

Corry RC, Lafortezza R (2006) Sensitivity of landscape measurement to changing grain size for fine-scale data representing highly-fragmented landscapes. Landsc Ecol Eng 3:47-53

Davies ZG, Pullin AS (2007) Are hedgerows effective corridors between fragments of woodland habitat? An evidencebased approach. Landsc Ecol 22:333-351

Di Falco S, Perrings C (2005) Crop biodiversity, risk management and the implications of agricultural assistance. Ecol Econ 55:459-466

Di Falco S, Penov I, Aleksiev A, van Rensburg TM (2010) Agrobiodiversity, farm profits and land fragmentation: evidence from Bulgaria. Land Use Policy 27:763-771

Dirimanova V (2006) Land fragmentation in Bulgaria: an obstacle for land marker development. Ann Pol Assoc Agric Agribus Econ 8:37-42

Dotterweich M (2008) The history of soil erosion and fluvial deposits in small catchments of central Europe: deciphering the long-term interaction between humans and the environment. Geomorphology 101:192-208

Elkie PC, Rempel RS, Carr AP (1999) Patch analyst user's manual: a tool for quantifying landscape structure. NWST technical manual TM-002. Ontario 
Fang B (2009) Poverty and biodiversity in rural areas based on two investigations in Pujiang County, China. J Environ Manag 90:1924-1932

Forman RTT, Baudry J (1984) Hedgerows and hedgerow network in landscape ecology. Environ Manag 8:499-510

Forman RTT, Godron M (1981) Patches and structural components for a landscape ecology. BioScience 31:733-740

Forman RTT, Godron M (1986) Landscape ecology. Wiley, New York

Geri F, Rocchini D, Chiarucci A (2010) Landscape metrics and topographical determinants of large-scale forest dynamics in a Mediterranean landscape. Landsc Urban Plan 95: $46-53$

Haines-Young R, Chopping M (1996) Quantifying landscape structure: a review of landscape indices and their application to forested landscapes. Prog Phys Geogr 20:418-445

Herzog F (1998) Streuobst: a traditional agroforestry system as a model for agroforestry development in temperate Europe. Agrofor Syst 42:61-80

Hildreth LA (2008) The economic impacts of agroforestry in the Northern Plains of China. Agrofor Syst 72:119-126

Hsiung W, Yang S, Tao Q (1995) Historical development of agroforestry in China. Agrofor Syst 30:227-287

Jose S (2009) Agroforestry for ecosystem services and environmental benefits: an overview. Agrofor Syst 76:1-10

Kim KH, Pauleit S (2007) Landscape character, biodiversity and land use planning: the case of Kwangju City Region, South Korea. Land Use Policy 24:264-274

Kobayashi Y, Koike F (2010) Separating the effects of land-use history and topography on the distribution of woody plant populations in a traditional rural landscape in Japan. Landsc Urban Plan 95:34-45

Lefroy EC, Hobbs RJ, O'Connor MH, Pate JS (1999) What can agriculture learn from natural ecosystems? Agrofor Syst 45:423-436

Lotfi A, Javelle A, Baudry J, Burel F (2010) Interdisciplinary analysis of hedgerow network landscapes' sustainability. Landsc Res 35:415-426

McGarigal K, Marks BJ (1995) FRAGSTATS: spatial pattern analysis program for quantifying landscape structure. Gen. Tech. Report PNW-GTR-351, USDA Forest Service, Pacific Northwest Research Station, Portland

Meeus JHA (1995) Pan-European landscapes. Landsc Urban Plan 31:57-79

Moser D, Zechmeister HG, Plutzar Ch, Sauberer N, Wrbka T, Grabherr G (2002) Landscape patch shape complexity as an effective measure for plant species richness in rural landscapes. Landsc Ecol 17:657-669
Pašakarnis G, Maliene V (2010) Towards sustainable rural development in Central and Eastern Europe: applying land consolidation. Land Use Policy 27:545-549

Poesen J, Vanwalleghem T, de Vente J, Knapen A, Verstraeten G, Martinez-Casasnovas JA (2006) Gully Erosion in Europe. In: Boardman J, Poesen J (eds) Soil erosion in Europe. Wiley, Chichester, pp 515-536

Ritters KH, O’Neill RV, Hunsaker CT, Wickham JD, Yankee DH, Timmins SP, Jones KB, Jackson BL (1995) A factor analysis of landscape pattern and structure metrics. Landsc Ecol 10(1):23-39

Rodzik J, Furtak T, Zgłobicki W (2009) The impact of snowmelt and heavy rainfall runoff on erosion rates in a gully system, Lublin Upland, Poland. Earth Surf Proc Land 34: 1938-1950

Rosenberg DK, Noon BR, Meslow EC (1997) Biological corridors: form, function and efficacy. BioScience 47: 677-687

Ruiz J, Domon G (2009) Analysis of landscape pattern change trajectories within areas of intensive agricultural use: case study in a watershed of southern Quebec, Canada. Landsc Ecol 24:419-432

Staniak M (2009) Zrównoważony rozwój obszarów wiejskich w aspekcie środowiskowym. Woda-Środowisko-Obszary wiejskie 27:187-194

Uuemaa E, Antrop M, Roosaare J, Marja R, Mander Ü (2009) Landscape metrics and indices: an overview of their use in landscape research. Living Rev. Landscape Res, 3. cited 17/06/2011. http://www.livingreviews.org/lrlr-2009-1

Van Dijk T (2007) Complications for traditional land consolidation in Central Europe. Geoforum 38:505-511

Waldhardt R, Simmering D, Otte A (2004) Estimation and prediction of plant species richness in a mosaic landscape. Landscape Ecol 19:211-226

Wischmeier WH, Smith DD (1978) Predicting rainfall erosion losses-a guide to conservation planning. USDA Agric. Handbook 537

With KA, Gardner RH, Turner MG (1997) Landscape connectivity and population distributions in heterogeneous environments. Oikos 78:151-169

Zgłobicki W, Baran-Zgłobicka B (2011) Gullies as an indicator of human impact on loess landscape (Case study: north western part of Lublin Upland, Poland). Z Geomorp Supp 55(1):119-137

Zgłobicki W, Rodzik J (2007) Heavy metals in slope deposits of loess areas of the Lublin Upland (E Poland). Catena 71:84-95 